\title{
A small new species of Crenicichla Heckel, 1840 from middle rio Xingu, Brazil (Teleostei: Cichlidae)
}

\author{
Priscila Madoka M. Ito and Lúcia H. Rapp Py-Daniel
}

A new species of Crenicichla is described from the middle rio Xingu and tributaries, upstream from Volta Grande do Xingu. The largest specimen measured $47.8 \mathrm{~mm}$ SL. The new species can be distinguished from all other Crenicichla species by the combination of the following character states: presence of serrae on supracleithrum (diagnostic of Crenicichla wallacii species group), large caudal blotch centrally located on caudal lateral line (shared with C. urosema and C. virgatula), vertical dark stripes on the caudal fin and up to three series of teeth on premaxilla and maxilla (vs. more than four series of teeth). The new species described herein is the eleventh species of Crenicichla listed from the rio Xingu basin. Similarities of color pattern among small species of Crenicichla is discussed.

Uma nova espécie de Crenicichla é descrita para o médio rio Xingu e seus afluentes acima de Volta Grande do Xingu. O maior espécime mede 47,8 mm CP. A nova espécie pode ser distinguida de todas as outras espécies de Crenicichla pela seguinte combinação de caracteres: presença de serrilhas no supracleitro (diagnóstico das espécies do grupo C. wallacii), ampla mancha caudal centralmente posicionada sobre a linha lateral caudal (compartilhada com C. urosema e C. virgatula), série de faixas verticais escuras entre os raios da nadadeira caudal e até três séries de dentes no premaxilar e dentário ( $v s$. mais de quatro séries de dentes). A nova espécie aqui descrita é a décima primeira espécie de Crenicichla listada para a bacia do rio Xingu. Semelhanças no padrão de coloração entre as espécies de Crenicichla de pequeno porte são discutidas.

Keywords: Amazon basin, Freshwater fishes, Morphology, Rio Bacajá, Taxonomy.

\section{Introduction}

Crenicichla Heckel, 1840 is currently recognized as the most species-rich among cichlids (Varella et al., 2012), with more than 85 valid species (Mattos et al., 2014), compared to 87 species of Apistogramma (Eschmeyer, 2015). Phylogenetic relationships within Crenicichla are still controversial. Based on a mitochondrial cytochrome $b$ gene analysis, Kullander et al. (2010) reported the monophyly of some previously defined Crenicichla species groups that were recognized based on morphology.

Kullander (1990) presented a discussion on small species of Crenicichla from the Amazon basin. He remarked that, besides length ( $\leq 75 \mathrm{~mm} \mathrm{SL})$, all Crenicichla species of reduced size should be grouped by the presence of serrations on the margin of the supracleithrum ( $v s$. absence in other Crenicichla). Ploeg (1991) informally grouped these small species in the Crenicichla wallacii group. Currently, the $C$. wallacii group comprises the following species: C. wallacii Regan, 1905; $C$. notophthalmus Regan, 1913; C. compressiceps Ploeg, 1986; C. heckeli Ploeg, 1989; C. regani Ploeg, 1989; C. urosema Kullander, 1990; and C. virgatula Ploeg, 1991.
The rio Xingu is a wide, clear water and fast-running river, stretching over large areas of rocks, and with its origins on the Brazilian Shield. During the dry season, large sandy beaches arise on the shores and clear water pools are easily seen. Kullander (1991) pointed out that many of the cichlids actually known to occur in the rio Xingu drainage actually also appear to occur in the rio Tocantins drainage. From the eleven valid species of Crenicichla registered for rio Xingu, three appear to be endemic.

Recent expeditions, some involved with the monitoring activities of the construction of the Belo Monte dam, a huge hydroelectic power facility in rio Xingu, yielded specimens of a new species being revised by the first author (PMI) as part of a larger revision of the C. wallacii group. This new species has been firstly noticed, but not formally named, by Kullander (1990, 1991), who pointed out the similarities shared between some small specimens of Crenicichla with C. urosema and $C$. virgatula but with a divergent color pattern. In the present paper, we formally describe this new species and discuss the overall similarities between the small Crenicichla species from rio Xingu.

Instituto Nacional de Pesquisas da Amazônia (INPA), Coleções de Peixes, Manaus - AM, Brasil. Avenida André Araújo, 2.936, Caixa Postal 2.223, 69060-001 Manaus, Amazonas, Brazil. (PMMI) priscila.ito@inpa.gov.br (corresponding author), (LHRP) lucia.rapp@ gmail.com 


\section{Material and Methods}

All material examined belong to the following collections: Academy of Natural Sciences of Drexel University (ANSP), Philadelphia, USA; Instituto Nacional de Pesquisas da Amazônia (INPA), Manaus, Amazonas, Brazil; Museu Paraense Emílio Goeldi (MPEG), Belém, Pará, Brazil; Museu de Zoologia da Universidade de São Paulo (MZUSP), São Paulo, Brazil; Universidade Federal do Pará (UFPA), Altamira, Pará, Brazil. Photographs of specimens of type series of the $C$. wallacii group are from the Natural History Museum (BMNH), London, United Kingdom.

Measurements, counts and color features were based on Kullander (1979, 1986, 1988). Body measurements were taken point to point with a digital caliper with 0.1 $\mathrm{mm}$ of precision, summarized in Table 1, and presented as percentages of Standard Length (SL) (except for SL which is presented as absolute numbers). In the text, counts from the holotype are indicated by an asterisk (*). Color markings terminology follows Kullander (1986) and Kullander \& Nijssen (1989).
For studies of internal anatomy, some specimens were cleared and double stained, following the protocol of Taylor \& Van Dyke (1985). Vertebrae counts were made on digital $\mathrm{X}$-ray images.

For conservation status, we used Geospatial Conservation Assessment Tool website (http:/geocat.kew. $\mathrm{org} /$ ) to calculate extent of occurrence (EOO) and area of occupancy (AOO), following IUCN Standards, through geocoordinates information of the examined material.

\section{Results}

\section{Crenicichla anamiri, new species}

urn:1sid:zoobank.org:act:49DA7992-4867-4436-8DA4D6A0F698D59B

Figs. 1-3

Crenicichla sp. cf. regani. -Warzel, 1992 [pointed as new species from Xingu river; aquarium magazine].

Crenicichla sp. aff. urosema. -Gottwald, 2007 [cataloged on aquarium magazine from Xingu river].

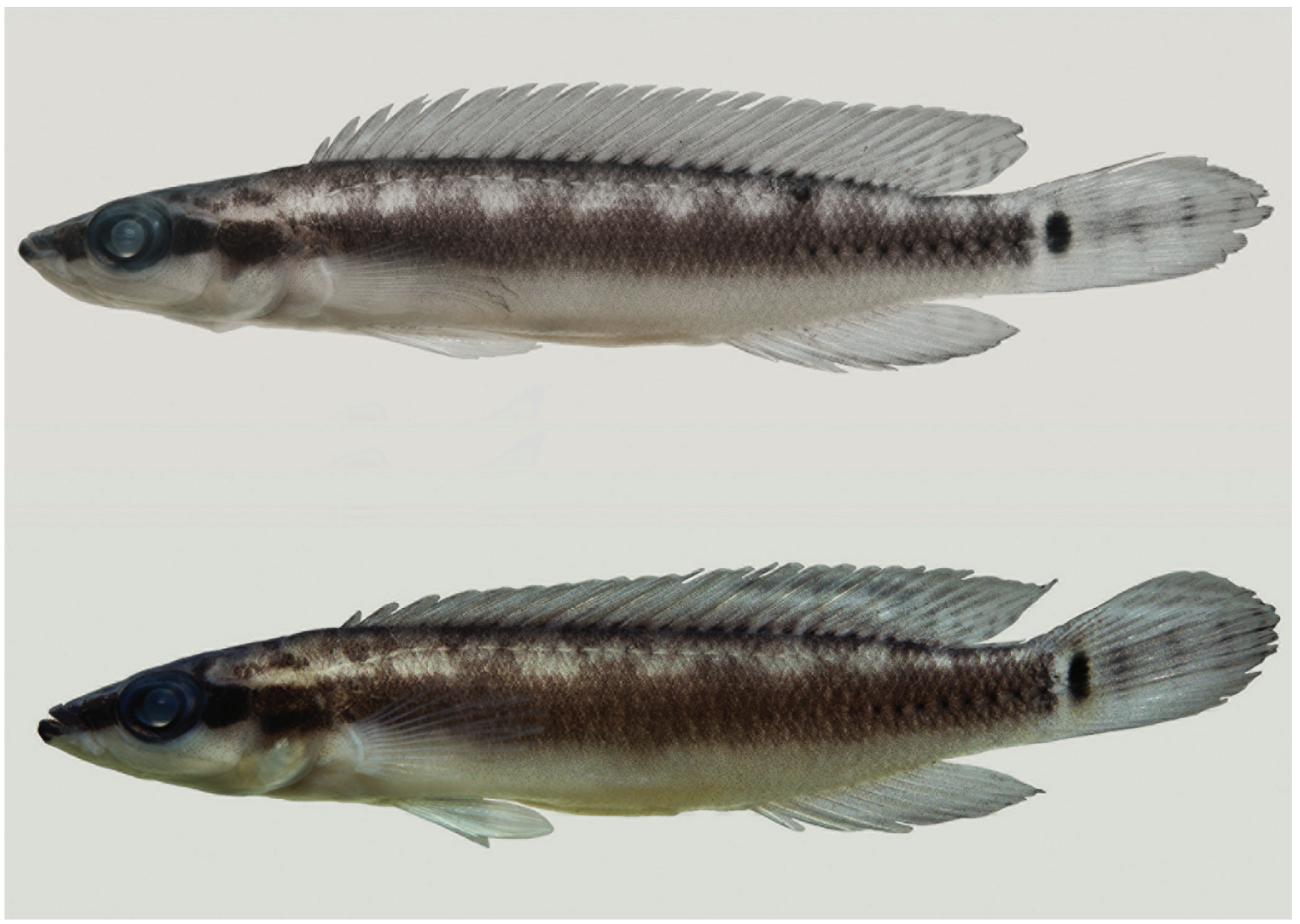

Fig. 1. Crenicichla anamiri, new species, holotype, male, INPA 46650, $42.9 \mathrm{~mm}$ SL, Itapuama, below confluence with rio Iriri, State of Pará, rio Xingu (above); paratype, female, INPA 46651, $43.3 \mathrm{~mm} \mathrm{SL}$, same locality of holotype (below). Photo by Douglas Bastos. 
Holotype. INPA 46650, $42.9 \mathrm{~mm}$ SL, Brazil, Pará, Itapuama, rio Xingu basin, rio Xingu below confluence with rio Iriri at beach margin with tree roots, $03^{\circ} 36^{\prime} 31^{\prime \prime} \mathrm{S}$ $52^{\circ} 20^{\prime} 58^{\prime}$ 'W, 04 Nov 2014, K. Winemiller.

Paratypes. Rio Xingu basin: ANSP 197277, 3, 30.3$47.8 \mathrm{~mm} \mathrm{SL}$, rio Itatá, right margin of rio Xingu, with litter on the bottom, $3^{\circ} 38^{\prime} 0.10^{\prime}$ 'S $51^{\circ} 49^{\prime} 33.60^{\prime \prime} \mathrm{W}, 10 \mathrm{Nov}$ 2014, A. Gonçalves et al. INPA 4176, 1, $41.0 \mathrm{~mm} \mathrm{SL}$, Babaquara island, rio Xingu, $03^{\circ} 18^{\prime} 14^{\prime \prime} \mathrm{S} 52^{\circ} 12^{\prime} 37^{\prime \prime} \mathrm{W}, 4$ Oct 1990, L. Rapp Py-Daniel \& J. Zuanon. INPA 4347, 3, 26.2-30.0 mm SL, Kaituka island, rio Xingu, 0333'47’'S 51'51'20"W, 9 Oct 1990, L. Rapp Py-Daniel \& J. Zuanon. INPA 37951, 2, 28.4-33.5 mm SL, rio Xingu, 03²0'57'S 52 11 '19”'W, 5 Out 2012, M. Sabaj Pérez, L. M. Sousa \& M. Arces. INPA 44341, 5, 18.5 - 32.3 mm SL (3, 27.9-32.3 $\mathrm{mm} \mathrm{SL}$ ), igarapé Balbino, rio Xingu, PARNA Serra do Pardo, 0548'05.5'S 52³5'56.6”'W, 21 Apr 2012, G. G. M. da Silva et al. INPA 44342, 1, $46.3 \mathrm{~mm}$ SL, igarapé Balbino, rio Xingu, PARNA Serra do Pardo, 0548'05.5'S 52³5'56.6"W, 21 Apr 2012, G. G. M. da Silva et al. INPA 44343, 1, $31.8 \mathrm{~mm}$ SL, igarapé Pontal, rio Xingu, PARNA Serra do Pardo, 0546’40.5”S 52 38'11.5”W, 20 Apr 2012, G. G. M. da Silva et al. INPA 44344, 8, 15.3 - $32.3 \mathrm{~mm} \mathrm{SL}$ (2 c\&s, 3, 25.1-32.3 mm SL), igarapé Balbino, rio Xingu, PARNA Serra do Pardo, 054'05.5”'S 52³5'56.6”W, 21 Apr 2012, G. G. M. da Silva et al. INPA 43933, 1, $44.0 \mathrm{~mm}$ SL, rio Bacajá, Pariaxá beach, rio Xingu, 0334'32.9"S 5135'54.8”W, 26 Nov 2012, A. Gonçalves, R. R. Sena, et al. INPA 46651, 4, $36.1-43.3 \mathrm{~mm} \mathrm{SL}$, same locality of holotype. MPEG 30442, 1, $39.2 \mathrm{~mm} \mathrm{SL}$, ilha Kaituka, rio Xingu, 03³3'47'S 51'51'20'”, 9 Oct 1990, L. Rapp PyDaniel \& J. Zuanon. MZUSP 108396, 14, 22.2-38.8 mm SL, igarapé Babaquara, next to Babaquara island, rio Xingu, 03²4’42”S 52¹2’32”W, 6 Jul 2010, Equipe ECIX.
Diagnosis. Distinguished from all other species of Crenicichla except $C$. notophthalmus, $C$. regani, $C$. urosema, and $C$. virgatula by the presence of serrations on supracleithrum (vs. absent). Distinguished from $C$. notophthalmus and C. regani by the presence of a black vertical elliptic blotch centrally positioned at caudal-fin base (vs. presence of ocellated blotch dorsally on caudalfin base). Distinguished from C. regani, C. urosema and C. virgatula by the presence of two to four rows of teeth in both jaws (vs. more than four rows); from C. virgatula and C. urosema also by the presence of vertical bars on the caudal fin ( $v s$. absence).

Description. Based on 44 specimens; largest specimen $47.8 \mathrm{~mm}$ SL. Measurements and counts given in Table 1. Body elongate, laterally compressed, head longer than deep. Body height increasing from snout to pectoral fin; uniform height from this point until caudal peduncle. Snout rounded in dorsal view, conic or moderately pointed in lateral view. Lower jaw slightly prognathous. Ascending premaxillary processes reaching to anterior orbital margin. Postlabial fold of upper jaw reaching to vertical line through nostril and postlabial fold of lower jaw reaching to vertical through anterior margin of orbit. Orbit lateral, not visible from below. Nostril dorsolateral, closer to dorsal margin of head than to tip of snout. Vertical margin of preopercle serrated, with series of 12-21 well-developed spines. Presence of one to six spines on posterior margin of supracleithrum.

Flank scales ctenoid. Cycloid scales on head, predorsal area, along dorsal-fin base, abdomen, between pelvic and anal fins, and along anal-fin base. Predorsal scales small and irregularly organized. Cheek with minute cycloid scales; four rows below eye. Circumpeduncular scale rows 18-22 (including lateral line).

Table 1. Morphometric data of Crenicichla anamiri sepatared for the holotype and remaining specimens examined. SD = Standard deviation; $\mathrm{n}=$ number of specimens.

\begin{tabular}{|c|c|c|c|c|c|c|}
\hline \multirow[b]{2}{*}{ Measurements } & \multirow[t]{2}{*}{ Holotype } & \multirow[b]{2}{*}{$\mathrm{N}$} & \multicolumn{4}{|c|}{ Range } \\
\hline & & & Min & Max & Mean & SD \\
\hline Standard Length $(\mathrm{mm})$ & 42.9 & 37 & 15.5 & 47.8 & & \\
\hline Body depth & 14.4 & 37 & 12.8 & 16.8 & 14.7 & 1.1 \\
\hline Head length & 28.1 & 37 & 26.3 & 31.8 & 29.6 & 1.1 \\
\hline Orbital diameter & 9.9 & 37 & 9.0 & 12.3 & 10.5 & 0.8 \\
\hline Interorbital width & 4.0 & 37 & 2.4 & 4.7 & 3.8 & 0.5 \\
\hline Snout length & 7.9 & 37 & 6.2 & 9.8 & 8.1 & 0.9 \\
\hline Upper jaw length & 7.7 & 37 & 7.4 & 9.2 & 8.3 & 0.4 \\
\hline Lower jaw length & 12.8 & 37 & 9.5 & 13.6 & 12.2 & 0.8 \\
\hline Caudal peduncle depth & 8.5 & 37 & 6.9 & 9.1 & 8.2 & 0.5 \\
\hline Caudal peduncle length & 13.1 & 37 & 11.5 & 15.2 & 13.4 & 0.7 \\
\hline Last dorsal spine length & 12.4 & 37 & 9.7 & 14.4 & 11.9 & 1.1 \\
\hline Pectoral fin length & 19.8 & 37 & 14.9 & 22.2 & 18.3 & 1.5 \\
\hline
\end{tabular}


Scales between upper lateral line and dorsal-fin base organized on 5-7 rows anteriorly, two posteriorly, three rows of scales between upper and lower lateral lines. Lateral line scales slightly larger and more elongate than others. Upper and lower lateral line with 19/7(2), 19/8(1), $20 / 7(1), 21 / 7(9), 21 / 8 *(10), 21 / 9(2), 22 / 7(6), 22 / 8(6)$, or $23 / 6(1)$, and lateral line scales on caudal fin with 1 (4) or $2 *(34)$. Scales of series E1 51(1), 55(2), 56(4), 57(4), 58(16), $59^{*}(10)$, or 60(1). Dorsal, anal, pectoral and pelvic fins without scales. Caudal-fin squamation extending to onefourth of caudal fin.

First dorsal spine length about one-fourth of last dorsal spine; spines increasing gradually in length until fifth, and subequal after sixth spine. Dorsal-fin spines and rays XVIII,8(1), XVIII,10(1), XIX,9(5), XIX,10(2), XIX,11(9), XX,8(1), XX,9(3), XX,10*(15), or XXI,9(1). Tip of soft-rayed portion of anal fin pointed, reaching to base of caudal. Anal-fin spines and rays III,7(1), III,8(18), III,9*(17), or III,10(2). Caudal fin rounded, with median rays slightly more elongated than others. Pectoral and pelvic fins slightly pointed, with median rays more elongated than others. Pectoral fin rays $13(6), 14 *(28)$, or 15(4). Pelvic fin inserted posterior to base of pectoral fin, with first ray longer and others decreasing in length.

Upper jaw with two to four rows, lower jaw with three to four rows. All teeth pointed and slightly curved posteriorly. Outer row teeth larger than inner row teeth.

First gill arch with $2(16), 3 *(22)$ gill rakers on epibranchial, and 6(3), 7(16), or $8 *(18)$ gill rakers on ceratobranchial. Microbranchiospines absent from all gill arches. Lower pharyngeal toothplates with developed incisiviform teeth; larger teeth at posterior border of plate. Lower pharyngeal toothplate with 19 teeth on posterior row and eight teeth on medial row (INPA 44344, 26.3mm SL) (Fig. 3).

Vertebrae. $\quad 17+13=30(2), \quad 17+14=31(3), \quad 17+15=32(3)$, $18+14=31(1)$.
Color in life. Broad longitudinal band along midlateral line of body densely black from tip of snout to opercle, dark grey from this point to end of caudal peduncle. Nine short, dark, vertical and irregular bars, with uncolored areas inside, connected to large and broad longitudinal band. Dorsum and top of head dull yellow, abdomen light yellow. Pectoral and pelvic fins hyaline. Dorsal and anal fins light yellow. Dorsal fin, in females, with thin, distal greyish submarginal band, followed by reddish orange stripe below, stretching from 15th spine to third or sixth soft ray. Caudal fin largely hyaline, with greyish borders and with four to five dark vertical elongate blotches. Largest and most conspicuous caudal-fin blotch centrally on base of fin, followed by three to four less conspicuous bars. Middle caudal-fin rays yellowish. Diagonal white stripes dorsoposteriorly on caudal fin (Fig. 2).

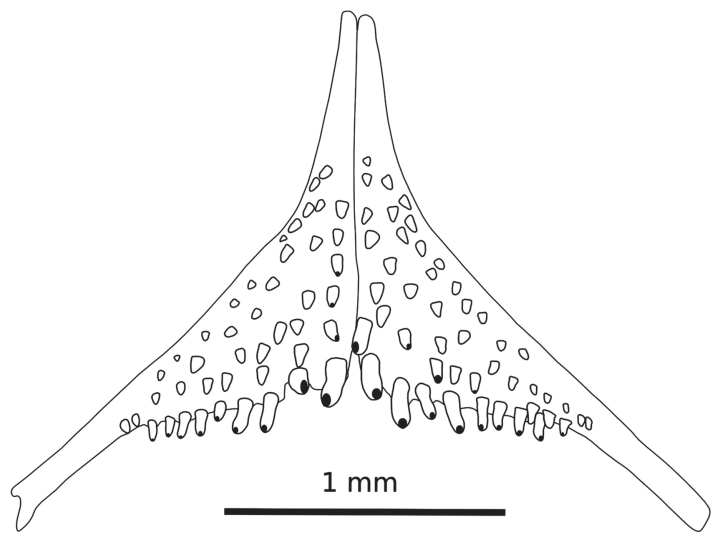

Fig. 3. Lower pharyngeal tooth plates of Crenicichla anamiri in occlusal view, INPA 44344, $26.3 \mathrm{~mm}$ SL.

Color in alcohol. Similar to live specimens but without orange and yellow pigments (Fig. 1).

Sexual dimorphism. Examined females presenting a color pattern different from males, as cited above on "Color in life" section (Fig. 2).

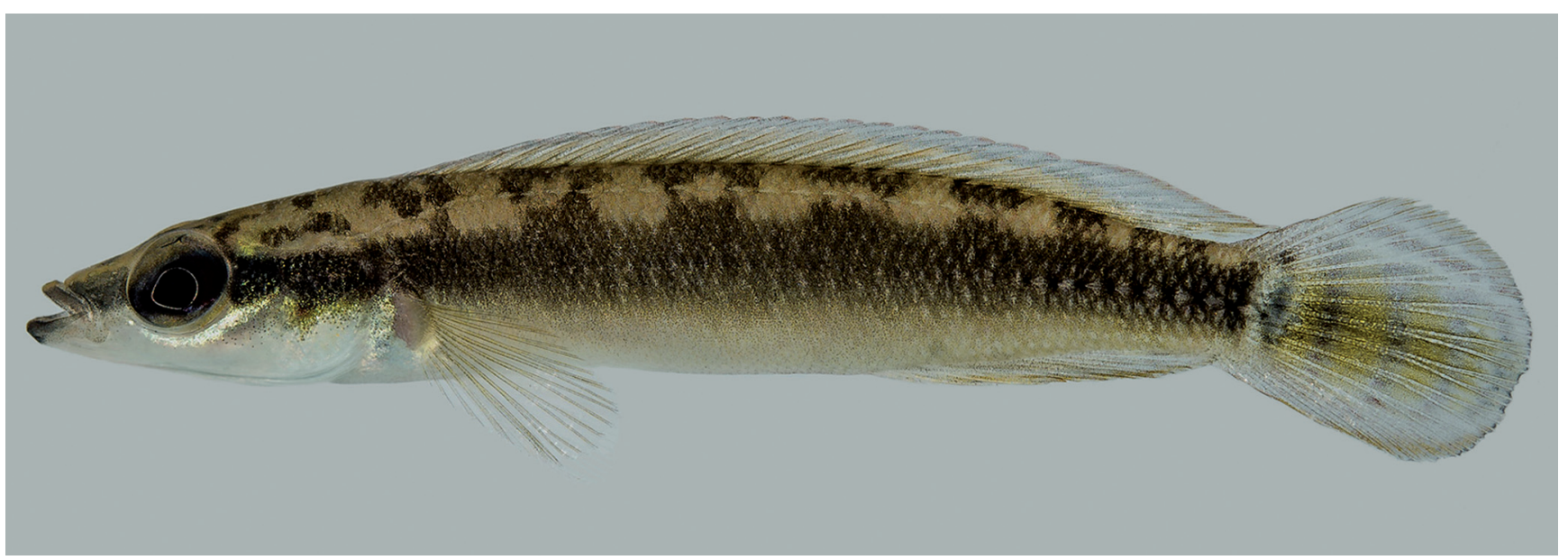

Fig. 2. Crenicichla anamiri, live specimen, paratype, INPA 46651, $43.3 \mathrm{~mm}$ SL, Brazil, State of Pará, Itapuama, rio Xingu. Photo by Leandro Sousa. 
Geographic distribution. All specimens were collected in middle rio Xingu and in rio Bacajá, upstream of Volta Grande do Xingu (Fig. 4).

Ecological notes. All specimens of Crenicichla anamiri were collected during the dry season (Fig. 5) using seine or dip-nets, close to the shore or on sandy beaches next to roots of the riparian vegetation.

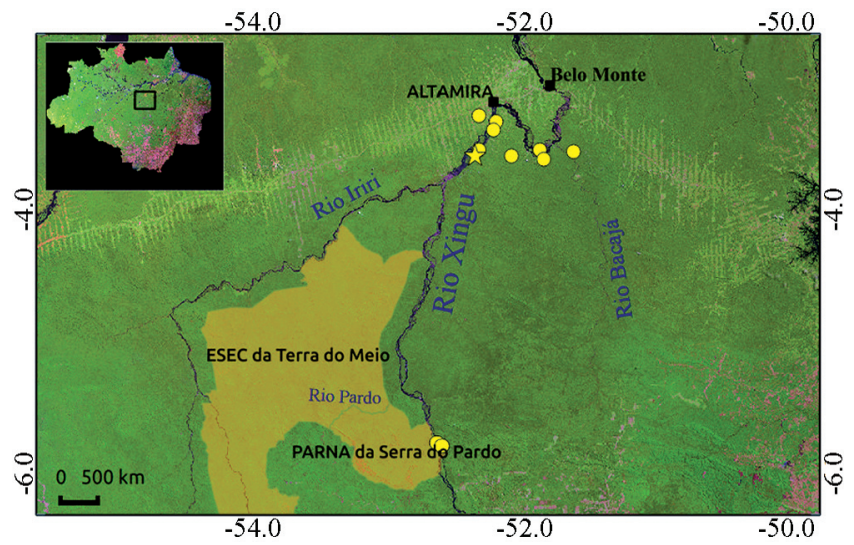

Fig. 4. Map of Northern Brazil and part of rio Xingu drainage showing collecting sites of Crenicichla anamiri. Some dots may represent more than one lot (star $=$ holotype).

Etymology. The name anamiri is a noun in apposition referring, in tupi-guarani, to the word "Anãmiri", meaning "dwarf", in allusion to the small size of the new species.
Remarks. The dark oval blotch on the middle of the base of the caudal fin is present only in three species of the $C$. wallacii group: Crenicichla urosema Kullander, 1990 (rio Tapajós drainage), C. virgatula Ploeg, 1991 (rio Branco drainage) and in $C$. anamiri (rio Xingu drainage). In the description of C. urosema, Kullander (1990) examined specimens of an undescribed species of rio Xingu (described herein as $C$. anamiri) and suggested that both species should be very close based on the presence of the midbasal caudal blotch. In another species, Crenicichla virgatula, the blotch on the caudal fin reaches from the sixth to the tenth ray and has an irregular elliptical shape, being round with a curved tail. In C. urosema, it extends from the fourth to the eleventh ray and it is larger. In C. anamiri, the caudal-fin blotch shows an intermediate position: it extends from the sixth to the eleventh caudal-fin ray and it is more centrally positioned on the fin, differently from $C$. virgatula and $C$. urosema, whose blotches are more dorsally concentrated (Fig. 6).

Examination of the holotypes of Crenicichla urosema and $C$. virgatula disclosed some morphometric and meristic differences when compared to $C$. anamiri, such as body depth of C. urosema and C. virgatula more than $17 \% \mathrm{SL}$ (vs. 14.4\% SL on C. anamiri); interorbital width more than $4.5 \% \mathrm{SL}$ (vs. $4.0 \% \mathrm{SL}$ on C. anamiri); four series of scales between the upper and lower lateral line on C. urosema, three series on $C$. virgatula and $C$. anamiri; upper/lower lateral line scales with $23 / 9$ on $C$. virgatula; $22 / 9$ on $C$. urosema and $21 / 8$ on C. anamiri.

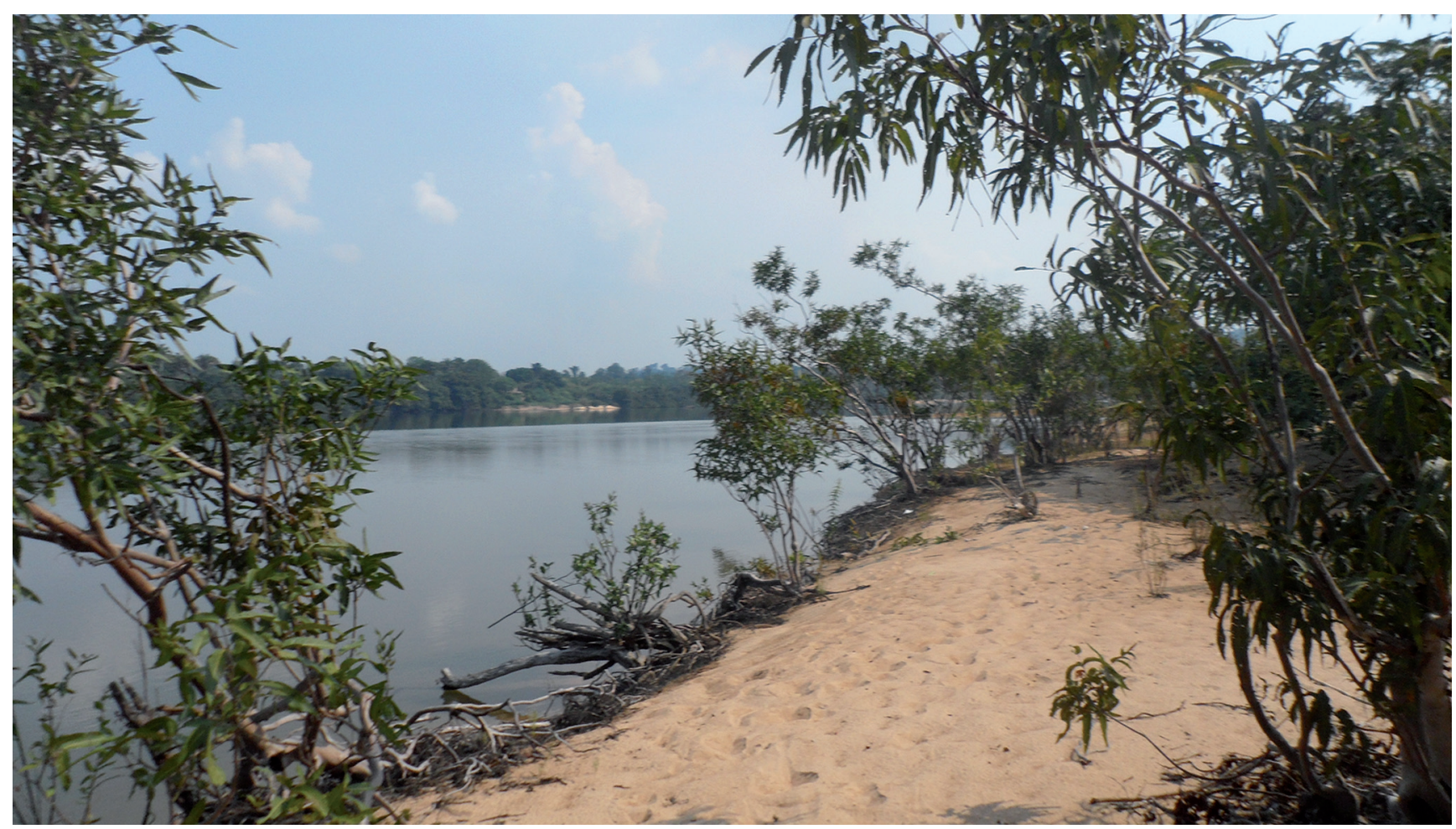

Fig. 5. Type locality of Crenicichla anamiri on the beach on rio Xingu, Itapuama, below the confluence between rio Xingu and rio Iriri, with roots of marginal trees. Photo taken during the Xingu expedition in the dry season (November 2014). 


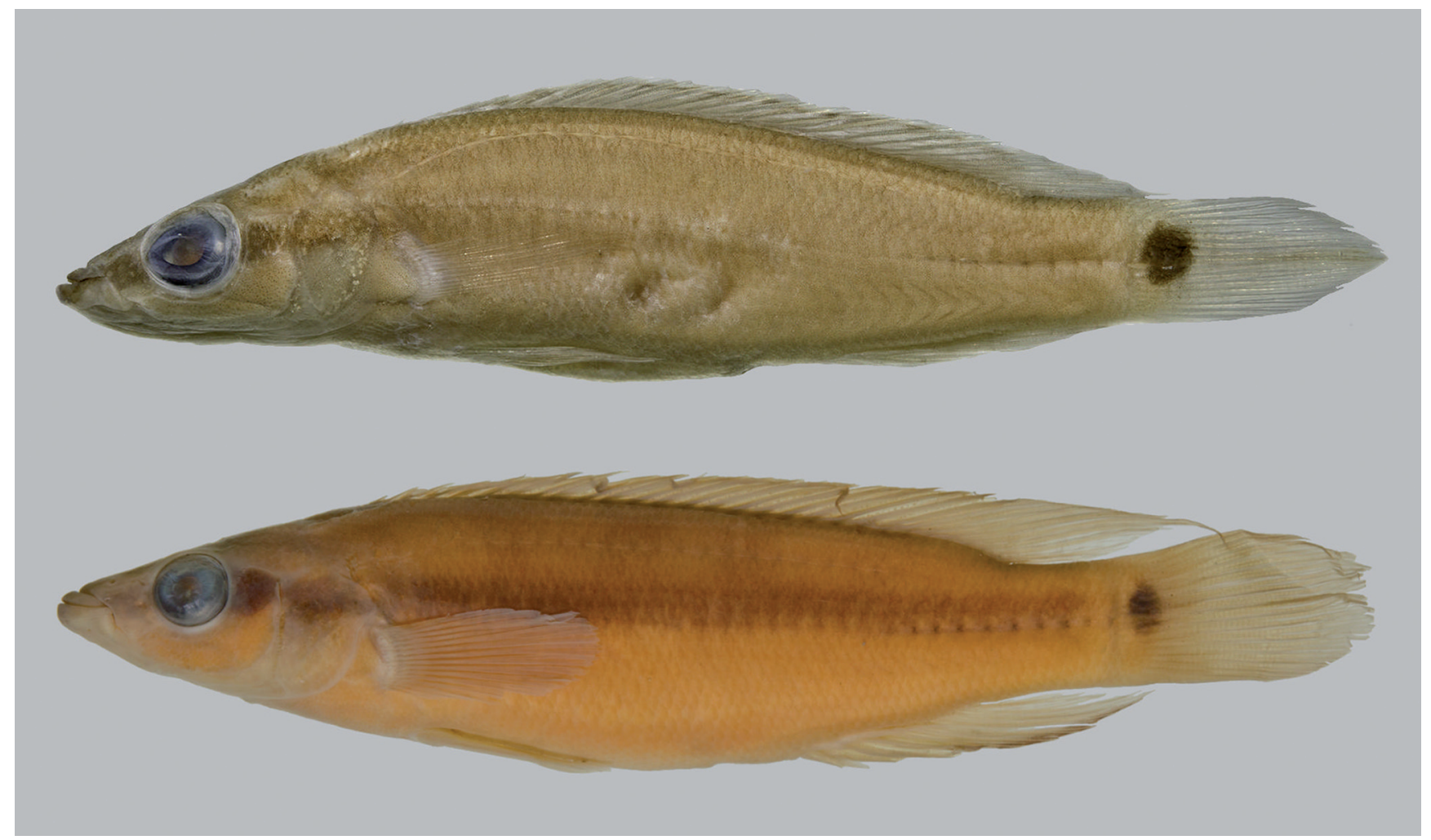

Fig. 6. Caudal blotch pattern in Crenicichla urosema, INPA 7010, $53.5 \mathrm{~mm}$ SL (above) and C. virgatula, INPA 2909, holotype, $66.2 \mathrm{~mm}$ SL (below).

The dark dots surrounded with white blotch on the base of the scales of the posterior lateral line on Crenicichla anamiri are also present in C. regani, C. urosema and $C$. virgatula, as well as in some species of rio Paraná and coastal Brazilian rivers (e.g., Crenicichla hu). These dots are also present on the base of the scales of the anterior and posterior lateral lines of Crenicichla macrophthalma, the type species of the genus. These dots, although not exclusively present in representatives of the $C$. wallacii group, may putatively further suggest a close relationship between $C$. urosema, $C$. virgatula and $C$. anamiri.

Crenicichla anamiri is the eleventh species of Crenicichla reported from the rio Xingu drainage. Crenicichla percna Kullander, 1991, C. phaiospilus Kullander, 1991 and C. rosemariae Kullander, 1997 were considered endemic. Crenicichla macrophthalma Heckel, 1840, C. johanna Heckel, 1840, C. marmorata Pellegrin, 1904 and C. regani Ploeg, 1989 are widely distributed in the Amazon basin and also occur in the lower rio Xingu (Ploeg, 1991). Crenicichla acutirostris Günther, 1862, C. strigata Günther, 1862 and C. inpa Ploeg, 1991 were mentioned to occur in rio Xingu by Ploeg (1991), but their taxonomic status are in need of revision, due to morphological variations and wide distribution. Statements on distribution of these three species might be premature.

Conservation status. The ongoing discovery of new taxa from the rio Xingu points out to the importance, lack of knowledge and concerns about the future of the ichthyofauna of this river basin. Crenicichla anamiri, like many other fish species in the rio Xingu, is apparently dependent of roots of trees on sandy beaches, and its area of occurrence includes Volta Grande do Xingu, one of the sites that is going to be largely affected by the construction of Belo Monte dam. This is a major hydroelectric power facility, almost completed, that will deviate the main course of the river towards a large reservoir. Considering the sample sites recorded for the species, $C$. anamiri would be classified as a NT (Nearly Threatened) species, according to the IUCN (International Union for Conservation of Nature) categories and criteria (IUCN Standards and Petitions Subcommittee, 2014). The estimated extent of occurrence (EOO) was $12,064.326 \mathrm{~km}^{2}$ (to be considered in the vulnerable category - VU, it would need to fall into the $\mathrm{B} 1$ criterion $<20,000 \mathrm{~km}^{2}$ ). The estimated area of occupancy (AOO) was $3,958.125 \mathrm{~km}^{2}$ (to be considered $\mathrm{VU}$, it would need to reach the criterion $\mathrm{B} 2<2,000 \mathrm{~km}^{2}$ ). In both cases, EOO and AOO fall short to a threatened category. Even with the Belo Monte dam, it seems that $C$. anamiri will not be strongly affected as other species that are heavily dependent on fast waters and rocky substrates. Besides, C. anamiri is registered to occur in the National Park (PARNA) of Serra do Pardo, a protected area located away from Belo Monte influence. Additional collecting efforts would certainly provide more information about the biology and resilience of this species. 
Comparative Material Examined. Crenicichla compressiceps: Brazil: Pará: INPA 855, $53.0 \mathrm{~mm}$ SL, holotype of $C$. compressiceps Ploeg, 1986, rapids below Jatobal, Tucuruí, rio Tocantins. INPA $862,3,19.4-23.7 \mathrm{~mm}$ SL, paratypes of C. compressiceps Ploeg, 1986, Tucuruí, rio Tocantins. INPA $878,10,31.0-57.3 \mathrm{~mm} \mathrm{SL}$, paratypes of $C$. compressiceps Ploeg, 1986, Jatobal, rio Tocantins. INPA 877, 1, $8.2 \mathrm{~mm}$ SL, paratypes of C. compressiceps Ploeg, 1986, Tucuruí, rio Tocantins. INPA 872, 5, 29.6-46.3 mm SL, paratypes of $C$. compressiceps Ploeg, 1986, igarapé Canoal, Breu Branco, rio Tocantins. INPA 977, 7, 31.0-43.7 mm SL, paratypes of C. compressiceps Ploeg, 1986, igarapé Canoal, Breu Branco, rio Tocantins. Crenicichla heckeli: Brazil: Pará: INPA 1496, 4, 40.6-46.9 mm SL, paratypes of $C$. heckeli Ploeg, 1989, Cachoeira Vira-Mundo, rio Trombetas. INPA 1497, 15, 30.8-52.0 mm SL, paratypes of C. heckeli Ploeg, 1989, Cachoeira Porteira, rio Trombetas. INPA 1500, 3, 37.1-51.2 mm SL, paratypes of C. heckeli Ploeg, 1989, Cachoeira Vira-Mundo, Oriximiná, rio Trombetas. INPA 1503, 1, 43.22 mm SL, paratype of C. heckeli Ploeg, 1989, Cachoeira Porteira, rio Trombetas. INPA 1504, 4, 35.2-52.2 mm SL, paratypes of C. heckeli Ploeg, 1989, Cachoeira Porteira, rio Trombetas. Crenicichla regani: Brazil: Amazonas: INPA 1434, 4, 40.1-79.3 mm SL, paratypes of $C$. regani Ploeg, 1989, lago Janauacá, Iranduba, rio Solimões. MZUSP 7423, 5, 39.8-66.6 mm SL, paratypes of C. regani Ploeg, 1989, small stream of lago Saracá, Silves, rio Maués. INPA 1444, 1, $4.0 \mathrm{~mm}$ SL, paratype of C. regani Ploeg, 1989, lago Jenipapo, rio Aripuanã. INPA 1795, 4, 35.2-41.9 mm SL, paratypes of $C$. regani Ploeg, 1989, $15 \mathrm{~km}$ below the bridge, Ji-Paraná, rio Machado. Brazil: Pará: INPA 861, 8, 29.8-39.8 mm SL, paratypes of C. regani Ploeg, 1989, igarapé Canoal, Breu Branco, rio Tocantins. INPA 864, 3, 36.9-39.7 mm SL, paratypes of C. regani Ploeg, 1989, igarapé Canoal, Breu Branco, rio Tocantins. Crenicichla urosema. Brazil: Pará: MZUSP 40289, 46.9 mm SL, holotype of C. urosema Kullander, 1990, rocky rapid of São Luiz, Itaituba, rio Tapajós. MZUSP 21851, 1, $53.0 \mathrm{~mm} \mathrm{SL}$, paratype of C. urosema Kullander, 1990, cachoeira Lombo de Anta, rio Tapajós. MZUSP 22019, 4, 38.7-53.6 mm SL, paratypes of C. urosema Kullander, 1990, well water with rocks at São Luiz, rio Tapajós. MZUSP 32872, 3, 40.9-57.7 mm SL, paratypes of C. urosema Kullander, 1990, well water with rocks at UHE of São Luiz, Itaituba, rio Tapajós. MZUSP 38298, 1, $68.8 \mathrm{~mm} \mathrm{SL}$, paratype of C. urosema Kullander, 1990, cachoeira Maranhãozinho, rio Tapajós. Crenicichla virgatula. Brazil: Roraima: INPA 2909, 66.2 mm SL, holotype of C. virgatula Ploeg, 1991, ilha Maracá, rio Uraricoera. INPA 2908, 3, 62.9-43.2 mm SL, paratypes of C. virgatula Ploeg, 1991, same locality of holotype. Crenicichla wallacii: Guyana: Potaro-Siparuni region: BMNH 1864.1.21.93, $85.0 \mathrm{~mm}$ SL, holotype of $C$. wallacii [photograph] Regan, 1905, Essequibo river. ANSP 176002, 10, 47.6-68.2 mm SL, Effluent of Turtle Pond, small isolated lake, Siparuni, Essequibo river. ANSP 179891, 3, 20.0-52.1 mm SL, Region 09, Rupununi river.

\section{Acknowledgments}

We are grateful to Leandro Sousa (UFPA, Altamira), Wolmar Wosiacki (MPEG), Kyle R. Luckenbill (ANSP) and fish collections of INPA, MZUSP, MPEG and Laboratório de Ictiologia de Altamira (UFPA - Altamira, Pará) for loan of the examined material; to Douglas Bastos (INPA) for taking photos and collecting part of the material; to Mark Sabaj-Pérez (ANSP), Kirk Winemiller (TAMU) and Alany Gonçalves (UFPA) for participating and actively collecting in the Xingu Project expeditions; to James Maclaine (BMNH) for images of the types of Crenicichla notophthalma and $C$. wallacii; and to André Galuch (INPA) for providing access to the ichthyoplankton lab's stereomicroscope for imaging of pharingeal plate. We thank the editor, Sven Kullander, and one anonymous reviewer for all the suggestions that greatly improved the manuscript. This work was part of the Master thesis of PMMI at INPA Graduate Program in Biologia de Água Doce e Pesca Interior (BADPI). Conselho Nacional de Desenvolvimento Científico e Tecnológico (CNPq) granted PMMI with graduate scholarship (process n. 134787/2011-0). We also benefited from material acquired with financial support from $\mathrm{CNPq}$ to LHRP (Edital Universal, process $\mathrm{n}$. 474236/2004-8). LRP also benefitted from a research grant from CNPq (process n. 309392/2011-0).

\section{References}

Eschmeyer, W. N. (Ed.). Catalog of fishes: genera, species, references. San Francisco, California Academy of Sciences. Available from: (http://researcharchive.calacademy.org/ research/ichthyology/catalog/fishcatmain.asp). (17 March 2015).

Gottwald, J. 2007. Die Crenicichla des rio Xingú. AquaristikFachmagazin, 193: 19-23.

Günther, A. 1862. Catalogue of the fishes in the British Museum. London, British Museum (Natural History), v. 4. 534p. Catalogue of the Acanthopterygii Pharyngognathi and Anacanthini in the collection of the British Museum.

Heckel, J. 1840. Johan Natterer's neue Flussfische Brasilien's nach den Beobachtungen und Mittheilungen des Entdeckers beschrieben. Annalen des Wiener Museumns der Naturgeschichte, 2: 327-470.

IUCN Standards and Petitions Subcommittee. 2014. Guidelines for using the IUCN Red List Categories and Criteria. Version 11. Prepared by the Standards and Petitions Subcommittee. Available from http://www.iucnredlist.org/documents/ RedListGuidelines.pdf. (31 May 2015).

Kullander, S. O. 1979. Species of Apistogramma (Teleostei, Cichlidae) from the Orinoco Drainage Basin, South America, with descriptions of four new species. Zoologica Scripta, 8: 69-79.

Kullander, S. O. 1986. Cichlid fishes of the Amazon River drainage of Peru. Stockholm, Swedish Museum of Natural History, 431p.

Kullander, S. O. 1988. Teleocichla, a new genus of South American rheophilic cichlid fishes with six new species (Teleostei: Cichlidae). Copeia, 1: 196-230. 
Kullander, S. O. 1990. A new species of Crenicichla (Teleostei: Cichlidae) from the rio Tapajós, Brazil, with comments on interrelationships of small crenicichline cichlids. Ichthyological Exploration of Freshwaters, 1: 85-93.

Kullander, S. O. 1991. Crenicichla phaiospilus and C. percna, two new species of pike cichlids (Teleostei: Cichlidae) from the rio Xingu, Brazil. Ichthyological Exploration of Freshwaters, 1: 351-360.

Kullander, S. O. 1997. Crenicichla rosemariae, a new species of pike cichlid (Teleostei, Cichlidae) from the upper Rio Xingu drainage, Brazil. Ichthyological Exploration of Freshwaters. 7: 279-288.

Kullander, S. O. \& H. Nijssen. 1989. The cichlids of Surinam: Teleostei: Labroidei. Leiden, E. J. Brill 256p.

Kullander, S. O., M. Norén, G. B. Friðriksson \& C. A. S. Lucena. 2010. Phylogenetic relationships of species of Crenicichla (Teleostei: Cichlidae) from southern South America based on the mitochondrial cytochrome $b$ gene. Journal of Zoological Systematics and Evolutionary Research, 48: 248-258.

Mattos, J. L., I. Schindler, F. P. Ottoni. \& M. M. Cheffe. 2014. A new species of Crenicichla from upper Rio das Antas basin, dos Patos lagoon system, southern Brazil (Teleostei: Cichlidae). Vertebrate Zoology, 64: 35-42.

Pellegrin, J. 1903. Contribution à l'étude anatomique, biologique et taxinomique des poissons de la famille des Cichlidés. Mémoires de la Société Zoologique de France, 16: 41-400.

Ploeg, A. 1986. The cichlid genus Crenicichla from the Tocantins River, state of Pará, Brazil, with descriptions of four new species (Pisces, Perciformes, Cichlidae). Beaufortia, 36: 57-80.
Ploeg, A. 1989. Zwei neue Arten der Gattung Crenicichla Heckel, 1840 aus dem Amazonasbecken, Brasilien (Pisces, Perciformes, Cichlidae). Aquarien-und Terrarienzeitschrift, 42: 163-167.

Ploeg, A. 1991. Revision of the South American cichlid genus Crenicichla Heckel, 1840 with descriptions of fifteen new species and considerations on species groups, phylogeny and biogeography (Pisces, Perciformes, Cichlidae). Academisch Proefschrift, Universiteit van Amsterdam, 153p.

Regan, C. T. 1905. A revision of the fishes of the South-American cichlid genera Crenacara, Batrachops, and Crenicichla. Proceedings of the Zoological Society of London, 1: 152-168.

Regan, C. T. 1913. A synopsis of the cichlid fishes of the genus Crenicichla. The Annals and Magazine of Natural History, 11: 498-504.

Taylor, W. R. \& G. C. Van Dyke. 1985. Revised procedures for staining and clearing small fishes and other vertebrates for bone and cartilage study. Cybium, 9: 107-119.

Varella, H. R., S. O. Kullander \& F. C. T. Lima. 2012. Crenicichla chicha, a new species of pike cichlid (Teleostei: Cichlidae) from the rio Papagaio, upper rio Tapajós basin, Mato Grosso, Brazil. Neotropical Ichthyology, 10: 233-244.

Warzel, F. 1992. Crenicichla species from the Rio Xingú. Pp. $77-$ 81. In: Konings, A. (Ed.). The Cichlids yearbook. St. LeonRot, Germany, Cichlid Press, v. 2.

Submitted July 17, 2014

Accepted June 16, 2015 by George Mattox Published September 25, 2015 